\title{
PENGARUH SISTEM VULKANISASI KONVENSIONAL (CV) DAN SEMI EFISIEN (SEV) TERHADAP SIFAT AGING DAN TERMAL VULKANISAT CAMPURAN KARET ALAM DAN KARET BUTIL
}

\section{THE EFFECT OF CONVENTIONAL (CV) AND SEMI EFFICIENT (SEV) CURING SYSTEM ON AGING AND THERMAL PROPERTIES OF NATURAL RUBBER AND BUTYL RUBBER BLENDS VULCANIZATES}

\author{
Arum Yuniari*, Muhammad Sholeh, Ihda Novia Indrajati \\ Balai Besar Kulit, Karet, dan Plastik, Jl. Sokonandi No. 9 Yogyakarta 55166, Indonesia \\ *Penulis korespondensi. Telp.: +62 274 521919, 563939; Fax.: +62 274563655 \\ E-mail: arumyuniari@yahoo.com
}

Diterima: 28 Mei 2015 Direvisi: 20 September 2015 Disetujui: 30 September 2015

\begin{abstract}
The purpose of this research was to study the effect of $C V$ and SEV curing systems on aging and thermal properties of natural rubber and butyl rubber blends. The mixing of rubber and rubber chemicals using two rollmills and the vulcanization process was carried out by the hydraulic press at $160^{\circ} \mathrm{C}$ and $150 \mathrm{~kg} / \mathrm{cm}^{2}$. The research design used two variations; first, the CV curing system (accelerator/sulfur) (1.0/2.5) phr and SEV curing system (accelerator/sulfur) (2.1/1.5) phr, second, the ratio of natural rubber/butyl: 100/0; 95/5; 90/10; 85/15; 80/20; 75/25; 70/30; 65/35; 60/40 and 55/45 phr. The parameter observed were tensile strength, elongation at break, hardness before and after aging and thermal properties, e.g. TG/DTA and DSC. The results showed that CV curing systems provided tensile, elongation at break properties gave higher quality and better aging properties. TG/DTA analysis of vulcanizates processed with CV curing systems provided slightly better thermal stability than of the SEV curing system.
\end{abstract}

Keywords: natural rubber, butyl rubber, curing, CV, SEV, aging, thermal.

ABSTRAK

Penelitian ini bertujuan untuk mempelajari pengaruh sistem vulkanisasi CV dan SEV terhadap sifat aging dan termal campuran karet alam dan karet butil. Pencampuran karet dan bahan kimia karet dilakukan menggunakan mesin two roll mil dan proses vulkanisasi dilakukan dengan mesin hydraulic press pada suhu $160^{\circ} \mathrm{C}$ dan tekanan 150 $\mathrm{kg} / \mathrm{cm}^{2}$. Rancangan penelitian menggunakan 2 variasi. Variasi pertama sistem vulkanisasi CV (akselerator/sulfur) $(1,0 / 2,5)$ phr dan sistem vulkanisasi SEV (akselerator/sulfur) $(2,1 / 1,5)$ phr. Variasi kedua adalah perbandingan karet alam/butil: 100/0; 95/5; 90/10; 85/15; 80/20;75/25; 70/30; 65/35; 60/40 dan 55/45 phr. Pengujian yang diamati adalah tegangan putus, perpanjangan putus, kekerasan sebelum dan sesudah aging serta sifat termal: DTA/TGA dan DSC. Hasil uji menunjukkan vulkanisat yang diproses dengan sistem vulkanisasi CV mempunyai sifat tegangan putus, perpanjangan putus lebih tinggi dan sifat aging lebih baik. Analisis DTA/TGA vulkanisat yang diproses dengan sistem vulkanisasi CV memberikan stabilitas termal sedikit lebih baik dari pada sistem vulkanisasi SEV.

Kata kunci: karet alam, karet butil, vulkanisasi, CV, SEV, aging, termal.

\section{PENDAHULUAN}

Pengolahan karet mentah menjadi produk karet dilakukan dengan cara vulkanisasi. Vulkanisasi adalah proses menghubungkan rantai makro molekul satu dan lainnya pada situs reaktif mereka. Sistem vulkanisasi yang digunakan untuk proses pematangan kompon karet ada tiga, yaitu konvensional, semi efisien, dan efisien. Pemilihan sistem vulkanisasi didasarkan pada beberapa pertimbangan antara lain: sifat vulkanisat yang diinginkan, proses dan risiko keamanan pada saat proses vulkanisasi. Dalam sistem vulkanisasi belerang, akselerator dapat membantu meningkatkan laju vulkanisasi kompon yang cenderung lambat jika hanya mengandung sulfur. Akselerator umumnya berupa senyawa organik yang digunakan pada proses komponding untuk mempercepat reaksi vulkanisasi kompon oleh sulfur. Sulfur merupakan 
bahan pemvulkanisasi yang dapat bereaksi dengan gugus aktif molekul karet yang pada proses vulkanisasi membentuk ikatan silang antar molekul karet sehingga terbentuk jaringan tiga dimensi.

Akselerator memberikan respon berbeda terhadap masing-masing karet. Umumnya karet sintetis memerlukan lebih banyak akselerator, sebaliknya karet alam membutuhkan banyak belerang. Karakteristik vulkanisasi merupakan metode yang digunakan untuk melihat laju reaksi vulkanisasi dari karet (Hasan et al., 2012). Sistem vulkanisasi yang sering digunakan adalah konvensional dengan rasio sulfur tinggi dibanding akselerator. Ikatan polisulfida yang dihasilkan membentuk jaringan yang sangat fleksibel sehingga menghasilkan sifat mekanik baik, tetapi dengan sifat aging kurang baik. Sistem vulkanisasi semi efisien adalah sistem dengan rasio sulfur rendah dibanding akselerator. Ikatan disulfidia akan membentuk vulkanisat yang mempunyai sifat tahan panas (Siriyong \& Keawwattana, 2012). Motar (2010) mempelajari proses pencampuran antara karet alam dan brominated butyl rubber (BIIR).

Pencampuran dari satu atau beberapa polimer secara fisika atau kimia dapat memperbaiki sifat fisika atau kimia dari campuran tersebut (Jovanovic et al., 2013). Karakteristik vulkanisasi campuran EPDM dan chloroprene rubber telah diteliti oleh Khalil et al. (2012). El-Nemr (2011) mempelajari pengaruh sistem vulkanisasi terhadap sifat mekanik dan sifat kimia vulkanisat acrylonitrile butadiene rubber. Sistem vulkanisasi konvensional memberikan sifat termal lebih baik daripada sistem vulkanisasi efisien (Yahya et al., 2011). Pencampuran antara karet alam dan karet sintetis membutuhkan sistem vulkanisasi yang tepat agar dihasilkan vulkanisat dengan sifat mekanis yang baik. Penelitian ini bertujuan mengetahui sifat termal dan aging dari campuran karet alam dan karet butil apabila divulkanisasi dengan sistem vulkanisasi konvensional dan semiefisien.

\section{BAHAN DAN METODE Bahan Penelitian}

Bahan baku yang digunakan adalah karet alam ribbed smoked sheet (RSS) dari PTPN IX, karet butil 301 merek Lanxess (densitas 0,92 mg/ $\mathrm{m}^{3}$, kadar abu max $0,8 \%$, dan viskositas mooney

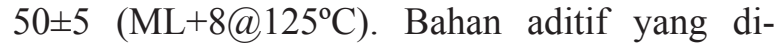
gunakan adalah: HAF black (N 330) dan nano precipitated calcium carbonate (NPCC) merek Diacal sebagai bahan pengisi, minyak parafinik sebagai plasticizer, tetrametildihidrokuinolina (TMQ) merek Kemai sebagai antioksidan, N-(1,3dimetilbutil)-N'-fenil-p-fenilendiamina (6PPD) merek Starchem sebagai antiozonan, seng oksida $(\mathrm{ZnO})$ dan asam stearat sebagai activator, aflux 42 sebagai promotor proses, parafin wax, tetrametil tiuram (TMT) dan merkapto benzotiazola (MBT) sebagai accelerator dan sulfur sebagai bahan pemvulkanisasi.

\section{Peralatan Penelitian}

Alat yang digunakan dalam penelitian ini meliputi alat proses dan alat uji yang terdiri dari: two roll mill, hydraulic press MN Vulcanizing Press, Spec XLB, D $400 \times 400 \times 1$, timbangan digital, tensile strength tester merek Troning Albert tipe QC II-M-18 dan merek Kao Tieh model KT 7010A, Seri 70287 kapasitas $500 \mathrm{~kg}$, hardness tester merek Toyoseiki (Durometer D), scanning electron microscopy (SEM) merek JEOL JSM-6360LA, DTA/TGA merek Perkin Elmer, DSC merek Perkin Elmer, dan oven merek Memert.

\section{Metode Penelitian}

Pembuatan kompon karet dilakukan dengan mencampurkan bahan-bahan kimia penyusun karet dengan karet alam dan karet butil. Tahapan proses pembuatan kompon karet diawali dengan penimbangan bahan yang diperlukan untuk masing-masing formulasi kompon. Jumlah dari setiap bahan di dalam formulasi kompon dinyatakan dalam phr (berat per seratus karet). Pencampuran karet dan bahan kimia karet dilakukan dalam gilingan terbuka (open mill). RSS dimastikasi selama 6 menit, dilanjutkan mastikasi karet butil selama 2 menit. Selanjutnya dilakukan pencampuran RSS dan karet butil selama 8 menit. Pencampuran polimer dan bahan pengisi carbon black dan NPCC selang seling dengan parafinic oil dilakukan selama 4 menit. Kemudian bahan kimia karet ditambahkan hingga homogen dengan lama waktu mastikasi 10 menit, bahan pemvulkanisasi (sulfur) ditambahkan, kemudian giling selama 2 menit. Kompon dikeluarkan dari open mill dan diletakkan di atas plastik transparan. Vulkanisat untuk keperluan pengujian dilakukan dengan pengepresan menggunakan hydraulic press pada suhu $160^{\circ} \mathrm{C}$, tekanan $150 \mathrm{~kg} / \mathrm{cm}^{2}$, dan waktu sesuai hasil pengujian rheometer.

Dalam penelitian ini dilakukan variasi bahan baku yaitu perbandingan RSS/karet butil: 100/0; 95/5; 90/10; 85/15; 80/20; 75/25; 70/30; 65/35; 
60/40; 55/45 phr, dan variasi sistem vulkanisasi konvensional (CV) accelerator/sulfur: $(1,0 / 2,5)$ phr dan sistem vulkanisasi semi efisien (SEV) $a c$ celerator/sulfur $(2,1 / 1,5) \mathrm{phr}$. Rancangan formulasi penelitian disajikan pada Tabel 1 .

Pengujian sifat aging yang dilakukan terhadap vulkanisat meliputi: tegangan putus dan perpanjangan putus awal dan sesudah aging pada suhu $100^{\circ} \mathrm{C}$ selama 70 jam (ISO 37), serta kekerasan sebelum dan sesudah perlakuan aging pada suhu $100^{\circ} \mathrm{C}$ selama 70 jam (JIS 6322).

Pengujian termal untuk TG/DTA menggunakan peralatan thermogravimetry analyser dan differential thermal analyser merek Perkin Elmer. Sampel yang digunakan berat $10 \mathrm{mg}$ untuk TG dan 23,169 mg untuk DTA, dipanaskan pada suhu $30-800^{\circ} \mathrm{C}$ dengan kecepatan $5^{\circ} \mathrm{C} /$ menit. Sedangkan untuk uji DSC digunakan peralatan merek Perkin Elmer, sampel yang digunakan berat $3,6 \mathrm{~g}$ dipanaskan pada suhu $400^{\circ} \mathrm{C}$ dengan kecepatan $5^{\circ} \mathrm{C} /$ menit.

\section{HASIL DAN PEMBAHASAN}

Pengaruh Sistem Vulkanisasi terhadap Sifat Tegangan Putus Vulkanisat RSS/Karet Butil

Sistem vulkanisasi sangat berpengaruh terhadap sifat tegangan putus. Tegangan putus vulkanisat dengan sistem CV (accelerator/sulfur $\mathrm{ra}$ tio) $(1 / 2,5) \mathrm{phr}$ lebih tinggi daripada sistem SEV (accelerator/sulfur ratio) $(2,1 / 1,5) \mathrm{phr}$ (Gambar 1).

Tegangan putus maksimum diperoleh pada vulkanisat RSS/karet butil (100/0) phr dan (90/5) phr, ini menunjukkan pada vulkanisat tersebut terbentuk ikatan silang cukup besar. Pada sistem CV,

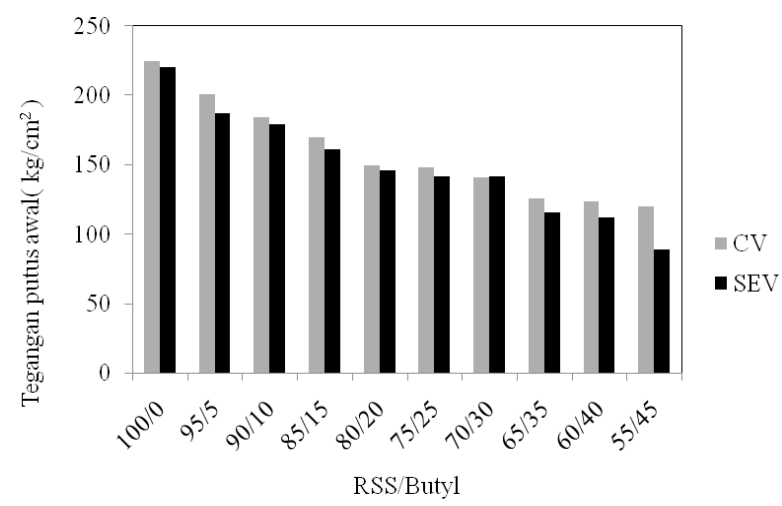

Gambar 1. Tegangan putus vulkanisat RSS/karet butyl dengan sistem CV dan SEV.

distribusi jaringan ikatan silang yang terbentuk homogen dan kompon mampu mengkristal dibawah tekanan sehingga akan menghasilkan tegangan putus tinggi. Kinerja sistem SEV secara signifikan lebih rendah untuk semua kompon campuran karet alam dan karet butil. Dalam kompon campuran karet alam dan karet butil tersebut kemungkinan terjadi jaringan non homogen karena adanya rongga pada ikatan silang yang dapat melemahkan sifat fisika (Gonzales et al., 2005).

Proses vulkanisasi sangat membutuhkan radikal bebas dari akselerator, sehingga jumlah akselerator sangat berpengaruh terhadap proses vulkanisasi. Radikal bebas disini berfungsi sebagai stabilisator. Akselerator dengan berat molekul tinggi mempunyai stabilitas tinggi. Dengan demikian dapat disimpulkan bahwa campuran karet alam/karet butil dapat menghasilkan tegangan putus tinggi bila diproses dengan sistem vulkanisasi $\mathrm{CV}$, hal ini disebabkan terbentuknya ikatan S-S

Tabel 1. Formulasi penelitian sistem vulkanisasi CV dan SEV.

\begin{tabular}{lcc}
\hline \multirow{2}{*}{ Bahan Baku } & \multicolumn{2}{c}{ Formulasi } \\
\cline { 2 - 3 } & CV & SEV \\
\hline RSS & variasi & variasi \\
Butil & variasi & variasi \\
Carbon black & 50 & 50 \\
NPCC & 5 & 5 \\
TMQ & 2 & 2 \\
6PPD & 1 & 1 \\
Wax & 0,5 & 0,5 \\
ZnO & 5 & 5 \\
Aflux & 1 & 1 \\
Parafinic oil & 8 & 8 \\
TMT & 0,5 & 1 \\
MBT & 0,5 & 1,1 \\
Sulfur & 2,5 & 1,5 \\
\hline
\end{tabular}


tinggi yang mampu menahan tekanan (Siriyong \& Keawwattana, 2012; Oh et al., 2014). Ikatan silang polisulfida akan terdistribusi secara homogen dan terjadi ikatan silang antara karbon-karbon. Sisi lain sistem SEV menghasilkan ikatan C-S yang berdampak pada sifat tegangan putus menjadi rendah. Proses polimerisasi dengan ikatan rantai yang saling berdekatan dapat menghambat kristalisasi campuran dan berdampak pada vulkanisat yang mudah putus (Siriyong \& Keawwattana, 2012). Bila ditinjau dari karet alam/karet butil, semakin tinggi kandungan karet butil, tegangan putus cenderung turun. RSS (karet alam) mempunyai sifat tegangan putus lebih tinggi dari karet butil. Penggunaan sulfur lebih banyak berpengaruh terhadap besarnya tegangan putus hal ini didukung oleh penelitian Yahya et al. (2011), Thomas et al. (2011), dan Ngudsuntear et al. (2014).

Pengaruh Sistem Vulkanisasi terhadap Sifat Perpanjangan Putus Vulkanisat RSS/Karet Butil

Perpanjangan putus vulkanisat campuran $\mathrm{RSS} /$ karet butil dengan sistem vulkanisasi CV dan SEV disajikan pada Gambar 2. Hasil uji menunjukkan bahwa perpanjangan putus sistem CV lebih tinggi dari SEV. Hal ini menunjukkan bahwa pada sistem CV memberikan kepadatan ikatan silang lebih banyak karena jumlah sulfur tersedia lebih banyak (Thiranan, 2007). Makin banyak terbentuk ikatan silang elastisitasnya makin tinggi. Sedangkan untuk sistem SEV ikatan silang yang terbentuk berkurang dan tidak merata. Hal ini menyebabkan kemampuan jaringan untuk mengkristal menurun. Semakin sedikitnya ikatan silang yang terbentuk menghasilkan akumulasi stress yang lebih rendah.

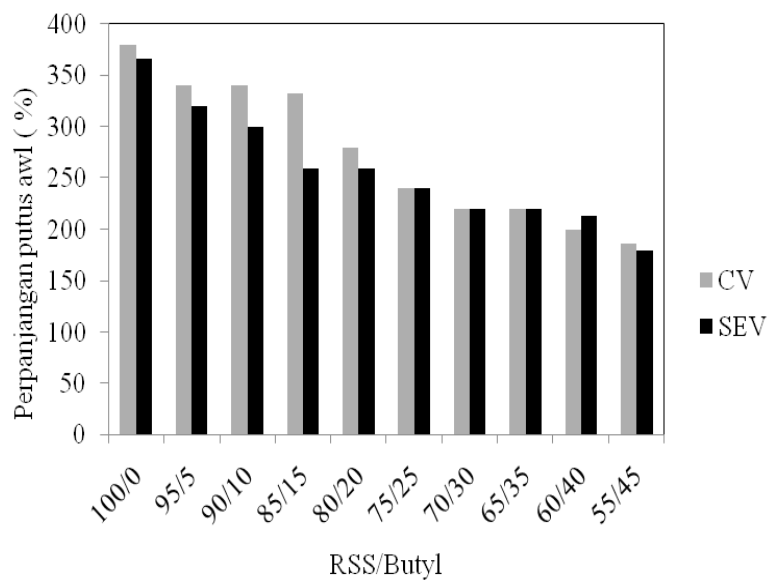

Gambar 2. Perpanjangan putus vulkanisat RSS/ karet butil dengan sistem CV dan SEV.
Bila ditinjau dari perbandingan RSS/karet butil, makin tinggi kadar karet butil, perpanjangan putus cenderung turun. Hal ini disebabkan karet alam lebih elastis dibandingkan karet butil. Perpanjangan putus tertinggi, pada vulkanisat karet alam/ karet butil ( $95 / 5$ phr) dengan sistem CV (accelerator/sulfur) $(1,0 / 2,5)$ phr yaitu sebesar $340 \%$.

\section{Pengaruh Sistem Vulkanisasi terhadap Sifat Kekerasan Vulkanisat RSS/Karet Butil}

Kekerasan merupakan salah satu persyaratan yang dibutuhkan dalam pembuatan barang-barang teknik. Kekerasan campuran tergantung dari kekerasan komponen-komponennya.

Vulkanisat dengan sistem SEV (Gambar 3) mempunyai nilai kekerasan sedikit lebih tinggi daripada vulkanisat sistem CV. Peningkatan kekerasan vulkanisat sangat dipengaruhi oleh kesesuaian sistem vulkanisasi yang digunakan. Sistem SEV sangat sesuai digunakan pada campuran karet alam dan butil, hal ini terbukti dengan nilai kekerasan yang meningkat. Thiranan (2007) melaporkan bahwa sistem CV bila digunakan pada campuran karet alam menghasilkan kekerasan lebih tinggi. Dengan demikian dapat disimpulkan bahwa sifat vulkanisat sangat dipengaruhi oleh sistem vulkanisasi dan jenis karet yang digunakan. Bila ditinjau dari perbandingan RSS/karet butil makin tinggi kadar butil kekerasan cenderung naik. Kekerasan tertinggi sebesar 62,83 Shore A, terjadi pada vulkanisat RSS/butil (65/35) dengan sistem SEV.

\section{Pengaruh Sistem Vulkanisasi terhadap Sifat} Tegangan Putus Vulkanisat sesudah Aging

Pengaruh termal aging pada sifat tegangan

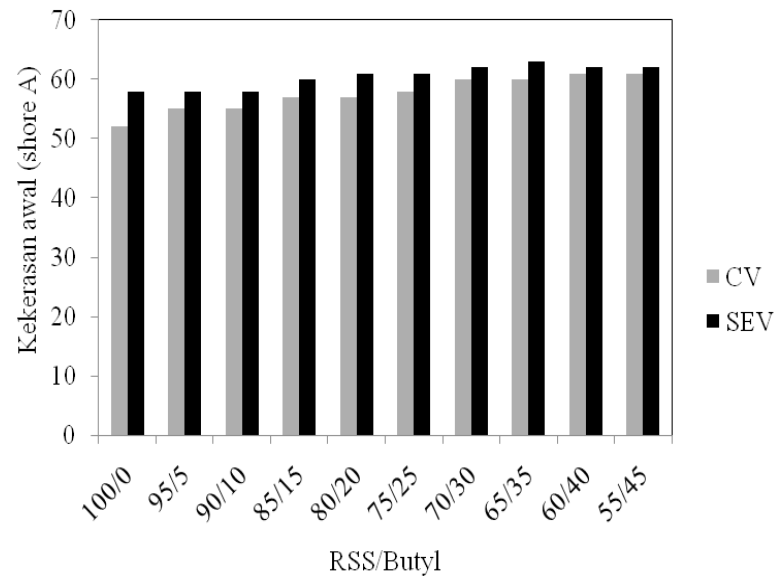

Gambar 3. Kekerasan vulkanisat RSS/karet butil sistem CV dan SEV. 
putus yang diproses dengan sistem CV dan SEV disajikan pada Gambar 4.

Hasil uji sifat tegangan putus sesudah aging ditunjukkan dengan perubahan nilai tegangan putus setelah dilakukan aging pada suhu $100^{\circ} \mathrm{C}$ selama 70 jam. Nilai tegangan putus menurun dengan perlakuan aging. Penurunan sifat tegangan putus untuk vulkanisat karet diproses dengan sistem SEV lebih besar bila dibandingkan dengan vulkanisat karet yang diproses dengan sistem CV. Pada tahap awal aging, pemutusan dan pembentukan ikatan silang baru ke dalam jaringan yang stabil dipengaruhi oleh sistem vulkanisasi. Vulkanisat dengan sistem CV memiliki kandungan polisulfida tinggi dengan kekuatan ikatan yang tinggi. Sebaliknya, hubungan monosulfida memiliki kekuatan ikatan rendah dan ini terjadi pada sistem SEV. Dengan demikian, campuran karet alam/karet butil dengan sistem CV lebih tahan aging dari sistem SEV.

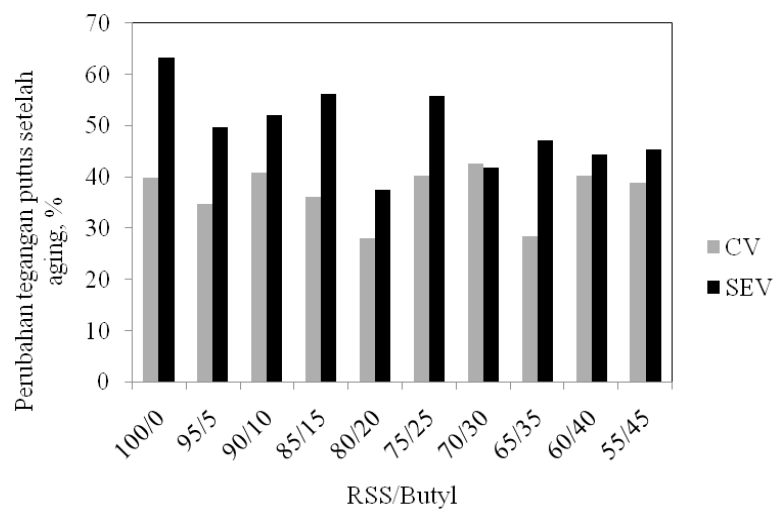

Gambar 4. Perubahan tegangan putus sesudah aging terhadap vulkanisat RSS/karet butil sistem CV dan SEV.

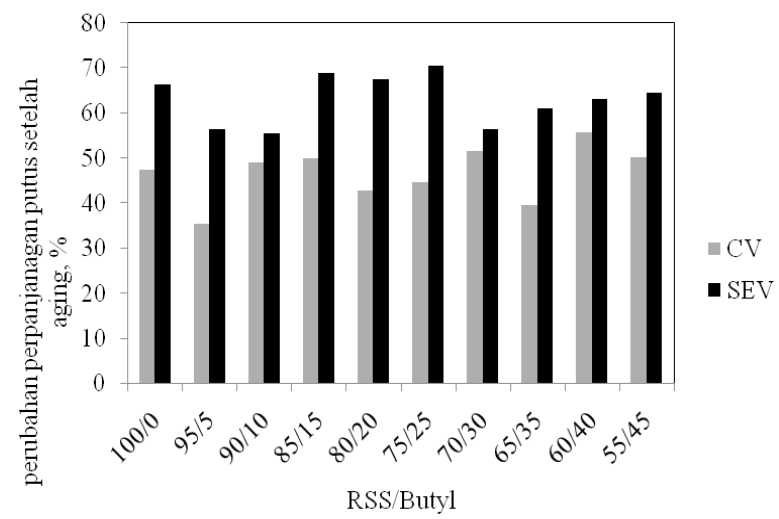

Gambar 5. Perubahan perpanjangan putus sesudah aging terhadap vulkanisat RSS/karet butil sistem CV dan SEV.
Vulkanisat RSS/karet butil diproses dengan sistem $\mathrm{CV}$ memberikan hasil lebih baik dimana nilai perubahan tegangan putus kecil bila dibandingkan dengan vulkanisat sistem SEV. Nilai terendah perubahan tegangan putus vulkanisat dengan sistem CV adalah sebesar 28,04\%.

Pengaruh Sistem Vulkanisasi terhadap Sifat Perpanjangan Putus setelah Aging Vulkanisat RSS/Karet Butil

Perpanjangan putus sesudah aging (Gambar 5) dimaksudkan untuk mengetahui perubahan sifat mekanik perpanjangan putus setelah dilakukan aging pada suhu $100^{\circ} \mathrm{C}$ selama 70 jam.

Hasil perpanjangan putus sesudah aging untuk kedua variasi sistem vulkanisasi terjadi perbedaan yang signifikan. Vulkanisat dengan sistem $\mathrm{CV}$ memiliki perubahan perpanjangan putus lebih rendah dibandingkan dengan vulkanisat sistem SEV. Hal ini menunjukkan vulkanisat tersebut mempunyai kualitas lebih baik karena elastisitasnya masih cukup tinggi setelah mengalami pemanasan.Vulkanisat RSS/karet butil (95/5) phr dengan sistem CV memiliki perubahan perpanjangan putus terkecil yaitu $35,29 \%$.

\section{Pengaruh Sistem Vulkanisasi terhadap Sifat Kekerasan Vulkanisat setelah Aging}

Perlakuan aging untuk karet bertujuan mengetahui kecepatan degradasi suatu vulkanisat fungsi dari suhu. Aging dilakukan pada suhu $100^{\circ} \mathrm{C}$ selama 72 jam, hasil uji aging kekerasan disajikan pada Gambar 6.

Kekerasan vulkanisat RSS/karet butil setelah dilakukan aging cenderung naik. Hal ini menunjukkan bahwa vulkanisat mengalami penurunan sifat

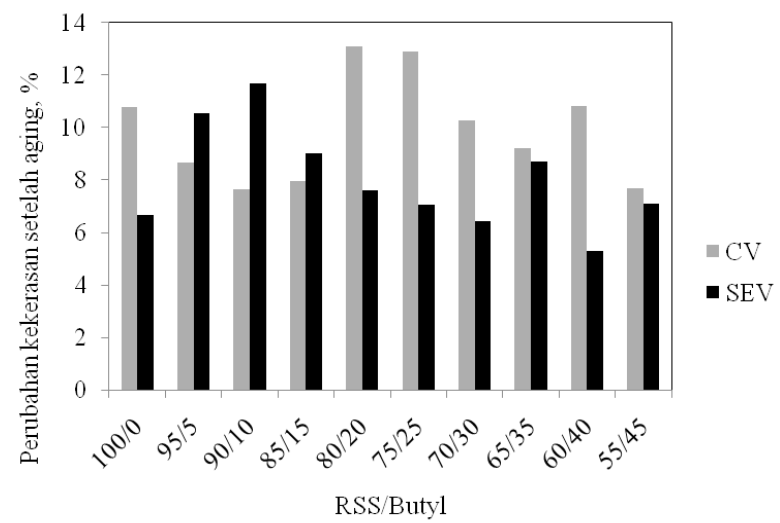

Gambar 6. Perubahan kekerasan sesudah aging terhadap vulkanisat yang diproses dengan sistem CV dan SEV. 
fisika karena terjadi degradasi akibat banyaknya ikatan rangkap yang putus. Perubahan kekerasan terbesar terjadi pada vulkanisat dengan sistem CV. Hal ini membuktikan sistem SEV lebih baik, karena perubahan kekerasan setelah aging kecil, dan ini menunjukkan ikatan rangkap yang putus lebih sedikit (Siriyong \& Keawwattana, 2012). Semakin tinggi kadar karet butil maka semakin tinggi ketahanannya terhadap aging (Gambar 5).

\section{TG dan DTA Vulkanisat Campuran RSS/karet Butil dengan Sistem CV dan SEV}

Pada Gambar 8 dan Gambar 9 tampak bahwa vulkanisat mulai mengalami perubahan atau reaksi yang ditunjukkan oleh penyimpangan terhadap garis horizontal.

Reaksi telah sempurna apabila tercapai kurva horizontal dan tidak mengalami perubahan kembali. Suatu bahan bila dipanaskan akan terjadi perubahan struktur yang mengakibatkan adanya perubahan dalam kapasitas panas atau energi termal bahan tersebut. Pengujian TG dan DTA untuk vulkanisat (RSS/karet butil) dilakukan pada kecepatan pemanasan $5{ }^{\circ} \mathrm{C} /$ menit dari suhu $30^{\circ} \mathrm{C}$

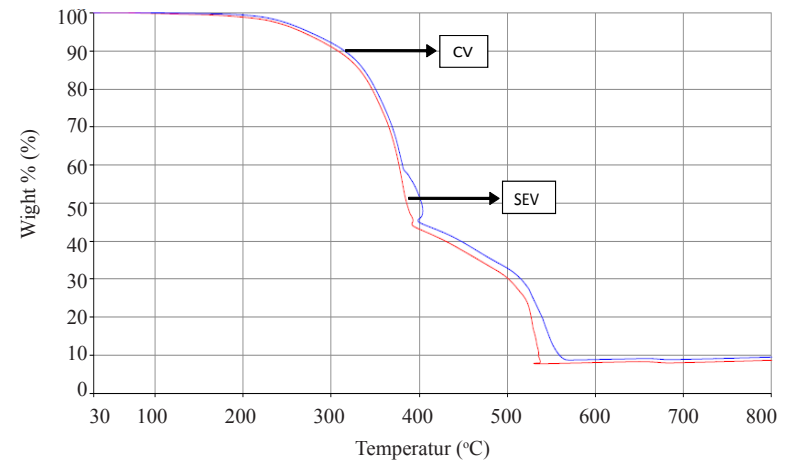

Gambar 8. TG vulkanisat RSS/karet butil/sulfur (55/45) sistem CV dan SEV.

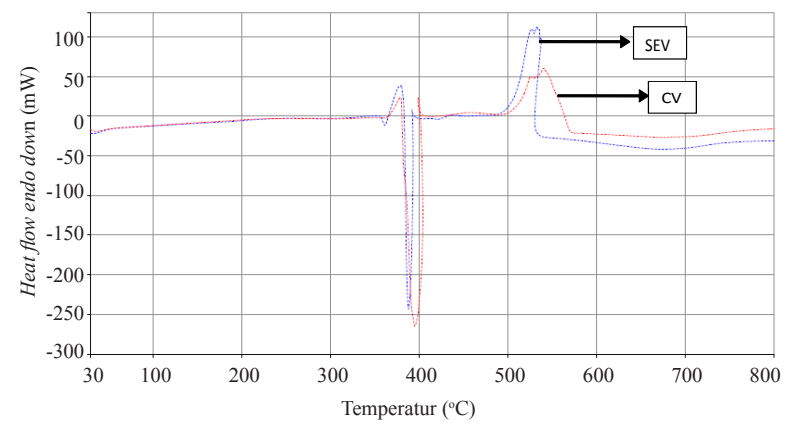

Gambar 9. DTA vulkanisat RSS/karet butil (55/45) phr sistem CV dan SEV. sampai suhu $800^{\circ} \mathrm{C}$. Hasil uji TG menunjukkan bahwa vulkanisat dengan sistem $\mathrm{CV}$ dan SEV mulai terdekomposisi pada suhu $210^{\circ} \mathrm{C}$. Pada kondisi pemanasan dinamis dekomposisi berlangsung pada suhu $250^{\circ} \mathrm{C}-530^{\circ} \mathrm{C}$ untuk vulkanisat dengan sistem SEV dan $250^{\circ} \mathrm{C}-560^{\circ} \mathrm{C}$ untuk vulkanisat dengan sistem CV. Reaksi dekomposisi sempurna pada rentang suhu $530^{\circ} \mathrm{C}-800^{\circ} \mathrm{C}$ untuk vulkanisat dengan sistem SEV dan $560^{\circ} \mathrm{C}-800^{\circ} \mathrm{C}$ untuk vulkanisat dengan sistem CV. Pada kondisi tersebut vulkanisat campuran karet alam dan karet butil terdekomposisi 90\%. Vulkanisat (RSS/karet butil) yang di vulkanisasi dengan sistem CV menghasilkan sifat termal yang lebih baik.

Perubahan termogram DTA disebabkan oleh perubahan panas reaksi dan dipengaruhi oleh perubahan massa vulkanisat tetapi juga oleh terjadinya proses perubahan struktur dan perubahan fase vulkanisat. Dari termogram DTA diperoleh perubahan kurva yang menunjukkan adanya perubahan massa panas reaksi. Hasil uji DTA (Gambar 8) menunjukkan terjadi reaksi endotermis. Puncak dekomposisi vulkanisat sistem SEV terjadi pada suhu $380^{\circ} \mathrm{C}$ dan pada suhu $400^{\circ} \mathrm{C}$ untuk sistem $\mathrm{CV}$, hal ini menunjukkan bahwa dengan sistem vulkanisasi berbeda maka suhu dekomposisi vulkanisat akan berubah.

\section{Differential Scanning Calorimetry (DSC)}

DSC termogram dimaksudkan untuk mengetahui titik kritis glass temperarure (Tg), temperatur kristalisasi (Tc), dan titik leleh (Tm). Analisis Tg dimaksudkan untuk mengetahui karakteristik non kristalin atau semi kristalin. Tg campuran karet alam dan butil terjadi pada suhu $150^{\circ} \mathrm{C}$ (Gambar 10), polimer amorf, semi kristalin cenderung keras dan rapuh. Proses yang terjadi ada-

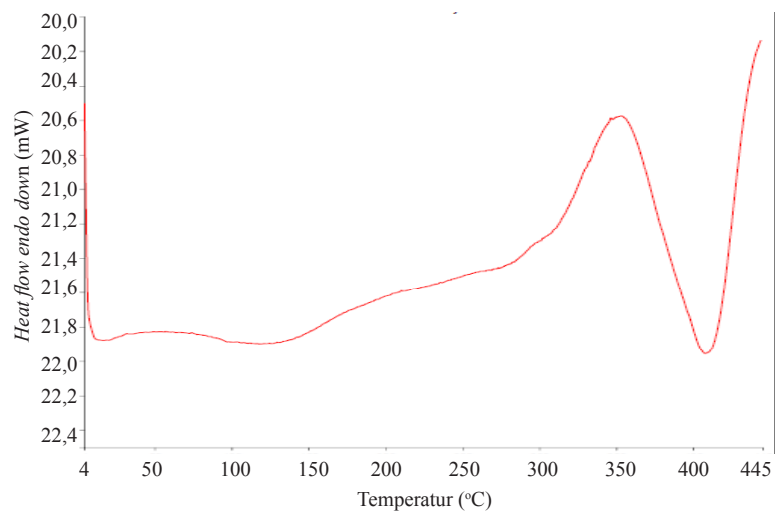

Gambar 10. DSC vulkanisat karet alam/butil (65/35) phr sistem CV. 
lah endotermis. Tc merupakan temperatur pada saat kristaliasi, proses yang terjadi eksotermis, kecepatan aliran panas akan naik. Tc vulkanisat terjadi pada suhu $290^{\circ} \mathrm{C}$. Tm merupakan suhu leleh, untuk mendeteksi perubahan material dari padat ke cair. Bila material mulai meleleh, ikatan intermolekuler akan mengabsorpsi energi, proses yang terjadi adalah endotermis. Tm terjadi pada suhu $400^{\circ} \mathrm{C}$.

\section{KESIMPULAN}

Penggunaan sistem vulkanisasi yang berbeda akan menghasilkan vulkanisat dengan sifat mekanis, aging, dan termal yang berbeda. Sistem vulkanisasi CV menghasilkan tegangan putus dan perpanjangan putus lebih baik daripada sistem SEV. Sistem SEV menghasilkan kekerasan lebih tinggi dari pada sistem CV. Vulkanisat dengan sistem CV mempunyai ketahanan aging lebih baik. Sifat termal vulkanisat dengan sistem $\mathrm{CV}$ sedikit lebih baik dari pada sistem SEV. Dekomposisi sempurna terjadi pada suhu $530^{\circ} \mathrm{C}$ untuk sistem SEV dan $560{ }^{\circ} \mathrm{C}$ untuk sistem CV. Hasil analisis DSC vulkanisat menunjukkan titik kritis temperatur sebagai berikut: $\mathrm{Tg}\left(150^{\circ} \mathrm{C}\right)$; $\mathrm{Tc}(290$ $\left.{ }^{\circ} \mathrm{C}\right)$; dan $\operatorname{Tm}\left(400^{\circ} \mathrm{C}\right)$.

\section{UCAPAN TERIMA KASIH}

Peneliti mengucapkan terima kasih kepada Kepala Balai Besar Kulit, Karet, dan Plastik yang sudah memberikan dana untuk kegiatan penelitian, serta kepada Bp Supriyanto dan Bp Parsono yang telah membantu dalam pelaksanaan kegiatan penelitian.

\section{DAFTAR PUSTAKA}

El-Nemr, K. F. (2011). Effect of different curing systems on the mechanical and physico-chemical properties of acrylonitrile butadiene rubber vulcanizates. Materials \& Design, 32(6), 3361-3369.

Gonzáles, L., Rodriguez, A., Valentin, J. L., MarcosFernandez, A., \& Posadas, P. (2005). Conventional and efficient crosslinking of natural rubber. Kautschuk und Gummi Kunststoffe, 58(12), 638643.
Hasan, A., Rochmadi, Sulistyo, H., \& Honggokusumo, A. (2012). The effect of rubber mixing process on the curing characteristics on natural rubber. Makara Teknologi, 6(2), 109-115.

Jovanović, V., Samaržija-Jovanović, S., BudinskiSimendić, J., Marković, G., \& MarinovićCincović, M. (2013). Composites based on carbon black reinforced NBR/EPDM rubber blends. Composites Part B: Engineering, 45(1), 333-340.

Khalil, A., Shaikh, S. N., Nudrat, Z. R., \& Khaula, S. (2012). Cure characteristics, mechanical and swelling properties of marble sludge filled EPDM modified chloroprene rubber blends. Advances in Materials Physics and Chemistry, 2(2), 1-8.

Motar, M. A. (2010). Inner tube of Al- Diwanyia tyre based on natural rubber blends. IBN Al-Haitham Journal For Pure and Applied Science, 23(1), 272-276.

Ngudsuntear, C., Limtrakul, S., Vatanatham, T., Wichien, A. N., Rempel, G. L., \& Arayapranee, W. (2014). Effect of blend ratio on cure characteristics mechanical properties, and aging resistance of silica-filled ENR/SBR blends. International Transaction Journal of Engineering, Management, \& Applied Science \& Technologies, 5(1), 11-24.

Oh, J., Yoo, Y. H., Yoo, I. S., Huh, Y. I., Chaki, T. K., \& Nah, C. (2014). Effect of plasticizer and curing system on freezing resistance of rubbers. Journal of Applied Polymer Science, 131(2).

Siriyong, T., \& Keawwattana, W. (2012). Utilization of different curing systems and natural zeolite as filler and absorbent for natural rubber/nitrile rubber blend. Kasetsart Journal Natural Science, 46, 918-930.

Thiranan, T. (2007). Utilization of various filler for rubber mat development (Thesis). Kasetsart University, Thailand.

Thomas, S., Mathew, E. J., \& Marykkutty, C. V. (2011). Synergic effect of N-benzylimine aminothioformamide secondary accelerator during sulfur vulcanization of a styrene-butadiene-natural rubber blend. Journal of Applied Polymer Science, 121(4), 2257-2263.

Yahya, Y. R., Azura, A. R., \& Ahmad, Z. (2011). Effect of curing systems on thermal degradation behaviour of natural rubber (SMR CV 60). Journal of Physical Science, 22(2), 1-14. 
